\title{
Thomas Moore and the Russian Literature of the 1820-1830 Years ${ }^{1}$
}

\author{
Tatiana Anatolievna Yashina \\ Candidate of Philology, Associate Professor, Penza State Technological University, Penza, Russia \\ Dmitry Nikolayevich Zhatkin
}

Doctor of Philology, Professor, Penza State Technological University, Penza, Russia

Email: ivb40@yandex.ru

Doi:10.5901/mjss.2015.v6n2s4p105

\begin{abstract}
The article deals firstly with the studying of Thomas Moore creative power in the context of the development tendencies of Russia literature in 1820-1830-years. It was also noted the Irish Melodies influence on the appearance or the Irish theme in the country periodicals and intensification of free-thinking motives in Russia poetry. There were also disclosed reasons of the eastern tale "Lalla Rouch» popularity in Russia which were corresponding to the blossoming of the Russian romantic orientalism and to the tendencies of the romantic poets investigation of the national originality by means of taking into account folk-lore and ethnography. In spite of the fact that the majority of early Thomas Moore translations into Russian were prosaic and were not done from the original works but from French middle translations the poetic works of the English author has become widely famous in Russia which can be proved by the appearance of reminiscences and traditions of Thomas Moore creative work in Russia romantic literature and including T. Moore poetry into the programme of educational establishments.
\end{abstract}

Keywords: Russian-English literary relations, English Romanticism, poetry, literary interpretation, intercultural communication

\section{Introduction}

Thomas Moore's first steps into the literary world were made with the translation of Odes of Anacreon and the creation of the original poems with the epicure, dominantly erotic content, - these works formed such author's books as "Odes of Anacreon" (1800) and "Poetical works" (1801). During these years young Moore deserved the reputation of the erotic poet in the classical style, and also started to be called Thomas the Little. His early epicurean poems were published under this name. From this side Moore was not so interesting to the Russian literature of the 1820-1830 years, as his hedonism motifs, got there high artistic mounting in the "Anacreon songs" (1804) by G.R. Derzhavin, were remarkably replaced and took the second place. Thomas Moore's collection of the creative works entitled "Epistles, odes and other poems" (1806), containing the critic evaluation of some parts of the modern life, also did not attract much attention. Thomas Moore deserved the literary popularity in Europe due to "Irish melodies" which were published by separate editions, from 1807 and during a period more than a quarter of the century. Thomas Moore is the author of the other important composition - an oriental romance "Lalla Rookh", appeared in 1817 and consisting of four distinct poems in the prosaic frame "The veiled prophet of Khorassan", "Paradise and the Peri", "The Fireworshippers", "The Light of the Harem". Thomas Moore, being an experienced writer up to this time, got his popularity in Russia as the author of "Lalla Rookh" and "Irish Melodies. Moore was taken by the Russian readers as one of the most outstanding representatives of the English Romanticism (in comparison with G. Byron, W. Scott) who greatly influenced many public men from the West European cultures and literatures.

Thomas Moore was not accompanied with the vision of the great legacy of the living classic writer, because many of his compositions in the 1820 years were known to the Russian literature society due to the poor French translations or even stayed unknown.

\footnotetext{
1 The article was prepared within the realization of the government task addressed the Russian department of education and science "Social-humanity investigations of different disciplines in the context of innovation development and international communication" in 2014 -2016 years.
} 


\section{Discussion}

Thomas Moore's creative work successfully combines specific national and common European features and can be differentiated by a great variety of the expression of artistic forms of some peculiarities particular to the romantic interpretation of the literature epoch. Moore transformed the idea of the literary inheritance and in the context of the national culture converted the problem of the individual style transformation into the ideological esthetic concentration which attracted the achievements of the previous generations - "the image system of the early Irish epos and folk songs colors of the melody rhythms, classical simplicity of the antic authors and brilliant achievements of the poets of the Elizabethan era, soul tension of the Baroque, elegance of the Rococo, intellectuality and publicity of the Renaissance" (1, p.1). The definite syncretism which was stipulated by the interaction of different styles in literature helped to create the individual originality of Thomas Moore's artistic investigations in the context of the English Romantic style.

Moore got new popularity in Russia by the middle of the 1820 years: he started to be spoken about as the closest friend of the recently died J. G. Byron, the person who was willed Byron's diary notes and other papers, which had without any questions a great historical, cultural and literary value. Moore's destruction of Byron's manuscripts was criticized by the Russian society which can be proved by observation of the private correspondence and some periodical editions. Only the publication of "Letters and journals of Lord Byron with notes of his life" in 1830 helped to change Moore's bad reputation, and also provoked a certain resonance in the literary society. This edition was taken for a long time as the most objective live evidence of the great English writer J. G. Byron.

In the 1820 years Moore was firmly recognized by the representatives of the Russian literary society, and M.P. Alekseev truly noticed that neither a great writer or any other in this century could ignore $(2, p$.$) the creative works of T$. Moore in different variants. This conclusion based on the deep factual investigation helped to evaluate the complexity and a great variety of interpretative forms of Thomas Moore's creative works in Russia. To sum up, the Russian reception of Thomas Moore is considered by the Russian philological science to be a bright literary phenomenon which was corresponded to the tendencies of the Russian-English cultural exchange and had its specific features during different periods of the literary development. Addressing to the Russian romantic literature in the 1820-1830 years, Thomas Moore's creative works was the first and the most important period of the English romantic interpretation in Russia. We think that Moore's compositions never got such emotional remarks of his admirers and at the same time so subjective as during the romantic period.

The majority of the early Russian interpretations of Thomas Moore's poetical works were prosaic but it was a general tendency of this epoch. It is known that in the critical reviews of 1822, written by P.A. Pletnev and based upon V.A. Zhukovsky's translation of Byron's "The Prisoner of Chilon", we can find his negative attitude to this tendency: "Until this time we read some Lord Byron's compositions in the prosaic interpretations. It is known that the poetry translated by the prose is the same as the music in the person's lips, who had listened it and rendered by himself" $(3, p .63)$. The existence of J.G. Byron, T. Moore and W. Scott's prosaic compositions in the press can be explained by the fact that this method of the artistic compositions interpretation was really easier than the poetic translation itself. It is true that poetical translations usually appeared after prosaic ones and were becoming a new stage in the acquaintance process of the Russian public with the creative works of the foreign writer. In this case we can give one more objective reason: the majority of early translators of Byron and Moore's works did not know the English language and that is why they used the French interpretations of the English romantic writers. Besides, in the French literature there were always used the prosaic English translations as the poetic original. Therefore, in many cases Russian interpreters did not have any real opportunity to recreate the lost poetic form after its translation from English into French.

The significant indicator of Thomas Moore's popularity in Russia became the inclusion of his poetic works of the second part of the 1820 years into the curriculum of educational establishments and their usage at English lessons. At Moscow University Noble Boarding School where many admires of T. Moore's creative works studied (among them were M.Y .Lermontov, D.P. Oznobishin), a great attention was paid to studying of foreign languages (English, French, German, Italian). Moreover, students made speeches in these languages during annually festivals. Among others we can mark the speech of Lermontov's classmate M.M. Ivanenko, pronounced in English during the festival act in 1830 - the artistic peculiarities of Thomas Moore creative works were considered in this speech (4, p.41-42). Among the advantages of "Irish Melodies" M.M. Ivanenko pointed out the poem harmony, the sweetness of patriotic feelings, consequence of poetic world reception with the national music, typical love of freedom, which did not bear the absence of depth or oppression. He also acknowledged some imperfect places in the poet's compositions: for instance, imperfection in the expression of the national coloring when the poems did not contain any local peculiarities, besides mentioning of the native Ireland.

An "Irish theme" in the Russian periodical issues, which is connected with the public and political events in the life of Ireland, was partly based on the materials of Thomas Moore's creative works in the Russian reception and this fact 
attracted the attention of G.A. Bauzhyte (pointed.: 5, p.275-301). Thomas Moore, having become a witness of the libertynational movement of Irish people, gave his early compositions from the poetic cycle "Irish Melodies", which did not have the complete final form, some elegiac manner, expressing the deep disappointment with the live realities. Gradually, with the long lasting and firm popularity in Russia "rrish Melodies" became the symbol of the Irish movement for freedom. Though Thomas Moore never pretended to be on the opposition side or the liberty fighter: protest ideas are not openly expressed in his poetic collection, they are given without any sharp words, thoughts about liberty are lost in the notes of penetrating lyrics, staying calm in any circumstances, be full of thoughtful sadness about unrealized dreams. A.P. Suruhanayn, characterizing the idea of "Irish Melodies", created by T. Moore and appeared in the middle of 1790 years in the Trinity college of the Dublin University, truthfully noticed that the political notes were sounding not so loudly in this poetic composition which discloses the Irish liberty movement periods in the XVIII and the first quarter of the XIX century and were appealed more to the past events rather than to the perspectives of the future struggle (6, p.258-259).

The idea of the poetic cycle, music basis for which were folk songs, appeared during the rise of the national liberty period, but its realization coincided with the period of the complex public processes, including the reaction processes connected with the completion of Napoleon wars. In 1822 in the journal "Blagonamerenny" there was issued a part of the poetical cycle which got a very great evaluation: "T. Moore happily surmounted all the difficulties of his work: his tone and rhyme are changing in his poems according to the voices they belong to: in one a young girl asks his hero, going to die for Erin country, never forget his lover; in another the fighters sing songs in honor to commemorate brave combats who glorified Ireland by their actions. Romantic views of Wicklow earls' lands, scenes of Avon and Avoke, superstitions of brave, sensitive, noble, passionate people got a new life and sounding with the help of Moore's creative muse; but we can more often hear the revenge voice of the oppressed people or sad voices of the defeated (7, p.47). As we can see, the translated article contains the definite characteristic of "War song" from the first book of "Irish Melodies", based on the story about the Irish king Brien Boromber who lived in the beginning of the XI century and was killed during the battle at Clopetarf. The words about Wicklow earls' lands, scenes of Avon and Avoca can be correlated with the other "melody" from the first book - "The meeting of the waters...", written after one of Moore's trips which got some valuable impressions.

"Irish Melodies" were not only often translated into the Russian language but partly included into the prosaic compositions of the Russian writes, used as the epigraphs. Russian translators of Moore's compositions, the writer who was considered one of the best European writers from the end of 1820 to the beginning of the 1830 years, was not always appreciated by the critics, whose conclusions did not coincide with the general readers' attention to the creative work of a talented Irish person. The traces of Moore's poetry in the Russian literature and culture could be observed up to the end of the XIX century, but by the middle of the 1830 years the English romantic compositions started to be determined as significant past events, the time when great and undead creators achieved their epoch, lost in the history forever. Moore's correlation with the past history period led to certain loss of interest to him from the side of the Russian literature society, but the interpreters continued to be attracted by some lyric compositions, mostly the poems which had intimate, music-melody basis with medium content, "National songs", elegies, friend's messages. The majority of underlined compositions were included into one of "Irish Melodies" parts, which had a long lasting life.

A great interest to Moore's compositions in Russia was closely connected with high development point of Russian oriental science, bright orient colors penetration into different compositions. It cannot be argued that that Russian writes preferences were greatly influenced by brightly colored oriental compositions of English, French, German romantic writers, taking into account "Lalla Rook" by Thomas Moore. But we cannot consider only Moore's experience as the writer who provoked the orient "fashion" in Russia. It is correct that "Lalla Rook" was suited for the frames of appeared tendency in searching national originality by romantic writers due to studying ethnography and folklore of different nationalities of people living on the territory of the Russian Empire. The proper investigation of people living in the east of Russia, on I.Y. Krachkovsky's opinion started in this period of time of $(8, p .84)$. Moreover appearance of "Lalla Rook" in Russia was determined not by historical and cultural interest to orient science but some public and political events - Berlin celebrations in 1821. An event, organized in honor of the future Emperor Nicolas the First and his wife Alexandra Fedorovna at the Prussian court, was oriented on the informal strengthening of relationship between the representatives of ruling dynasties. Celebration participants were not only famous guests but also the Royal House members and the most part of its suit. In the theatre performance, based on Thomas's subject which represented the wedding train "Lalla Rook" on the way of its travelling, there were shown "life pictures", describing the parts from "Lalla Rook" poem. Each scene was accompanied by the romance singing, its words were intended to explain the speechless action on the stage. Court composer G.L. Spontiny wrote music to the romances and it was sung by famous singers Miller, Zeidler, Shultz and Buder. Berlin celebration impressions, staying for a long time in the memory of Nicolas the First and his wife Alexandra Fedorovna, kept reminding them (with their close friends) again and again of the images and ideals of "Lalla Rook". 
Zhykovsky's impressions after this celebration event helped him to create the bright interpretation of the second inserted poem "Peri and Paradise" in 1821 and some other literary compositions.

Thomas Moore's poem "The Loves of the Angels", written in 1823, also got a certain popularity in Russia. Its critic reviews of the period from 1820 until 1830 were not deep but declarative or sharp and critical, which can be connected with the fear to evaluate the poetic interpretations of the religious matter. Erotic interpretation of the Bible stories, suggested by Moore, thought to be distrustful, moreover, Pushkin's "Gavriliada" was recently judged by the church critics and the issue of Parny and de Vini's erotic compositions was defined as free-thinking actions or political liberalism. At last the Byron's "mystery" of "Heavens and the Earth" (1822) was forbidden in Russia because according to the critic's opinion we can feel "the writer's intention to show that God was untruthful and cruel". (9, p.260). Church censorship was disturbed by the description of angels dating with Earth girls just as before the Flood eve. Though such narrations were based on the sixth part of the Bible "The Book of Genesis" which initiated a lot of argument, according to its content God's sons married most beautiful daughters of people; Heaven's sons eagerly wanted Earth's sons, as it was spoken in the apocriphic "Book of Enoch", found in Ethiopia and on Byron's view, written before the Great Flood.

Moore used the same sources of information in his poem as Byron in his "Mystery" "The Heavens and the Earth", in spite of which both compositions were created separately from each other but at the same period of time ("accidental coincidence"), the Irish poet pointed on this fact in the "Life of Angels" (10, p.246. Thus, it was greatly important for Byron to express people's suffering of the angels, the love picture of seraphims Azazil and Samiaz, children of Kainane and Agolibame, but for Moor it was important to show three fighting angels' destinies, who were punished by God for their pride, independence and a wish to learn forbidden things. It is out of question that allegoric scenes of "The Lovers of Angels" were optimistically colored, which was based on the destiny's reconciliation and God's help faith, on the other hand Byron's mystery contains a hidden protest against all-powered people, destructing the soul harmony. So, according to this fact, Moore's composition must provoke more pleasant attitude of the church censorship in comparison with Byron's mystery, but the partial equality with the Bible end the fear of meaning loss of the Bible original texts which were so strong that "The Love of the Angels" seemed to be dangerous free-thinking composition.

Prosaic translation of Thomas Moore's novel "The Epicurean", published as a separate book in 1827, was written though seven years earlier and seemed to be little archaic in the presence of creating new historical novels by Walter Scott. Moore's interest to early Christian literature, Middle Ages history of east and west Europe was reflected in this composition. The author paid great attention to numerous historical sources and a big list of additional literature proving the guarantee of true historical description, attached to the novel. But in reality the author could not always operate the latest historical knowledge, many facts of which were not fixed in the written documents, were created with the help of author's imagination and it led to the appearance of artificial, less true facts in the plot of the novel. The life-story of the Greek-Epicurean young men Alkifron, who changed his religion into Christian one with the help of young Egyptian priestess and then died, being accused for prison work in the Pyramids' basement, got critical marks in the literature societies of England and France. The novel was not also popular in Russia, though the first five chapters' translation were done by V. Malstev in 1829 and published in one of the issues of "Russian Spectator" (11, p.105-142). Maltsev attentively took into account Moore's poetic insertions into the prosaic text and successfully translated three poetic parts of it. But in comparison with V. Maltsev A. Savitsky made the complete "Epicurean" interpretation (12), but missed all the poems and the most part of notes; because he might use not English original text but greatly simplified French interpretation. Thus, the novel was read in original language in St. Petersburg and it can be proved by the English epigraph usage on the first page of the book 'Salarm or the flowers language", published by D.P. Oznobishin in 1830.

After the publication of two volumes of T. Moore's book "Letters and journals of Lord Byron with notes of his life", he became rather a famous English writer's friend and the writer of his biography than an original writer. The book which draws great attention of many readers, was close to their traditional acknowledgments, and it paid attention to the most attractive part of Byron's active life and did not concern difficult questions of his soul and temper searching. Moore was considered as a talented writer in the reader's reception at the beginning of the 1820 years, but when the information of him as a close Byron's friend appeared, a new stage of his reception started. Byron's style was one of the most popular attractions in the Russian Romantic literature (pointed: 13, p.61-63), meanwhile peaceful melancholy of Moore's poetry cannot suggest some new peculiarities or poetic devices. Continuous admiration of Byron's great talent, which was full of soul sickness and fighting, was combined with mistrusting of Moore's creative investigation: his "Eastern poem" "Lalla Rook" often seemed to be full of unnatural oriental motives; "Irish Melodies" were different by their specific ethnic coloring of civil author's position, in many cases they sounded too beautiful in the music form. 


\section{Conclusion}

The interest losing of Moore's creative works in 1840 can be explained by the general tendency of losing poetry attraction in the readers' minds. V.G. Belinsky thought over this tendency in an accurate review "Russian literature in 1843": "Poems are seldom read nowadays, but magazines still traditionally attract reader's attention and are full of a great variety of poems». We can find some poems in the magazines which are full of poetic feelings but are not so valuable as before, and it is true that their creators must change their lyres and sign other songs or they cannot fight for the attention and sympathy of the readers.(14, p.94-95). The right Belinsky's remark about past respect initiated some poets to take into account Thomas Moore's inheritance, at first "rish Melodies" and the cycle of "National songs". Among the interpretations there were the texts translated into Russian before, however, the amount of the interpretations, known to the Russian readers, was very small. There was not a great number of popular poets and professional interpreters who noticed Moore's creative works inheritance that is why accidental and unprofessional interpretations of that time could not provoke a new period for the popularization of Moore's compositions in Russia.

To conclude, we firstly made the investigation of Thomas Moore's creative works in the basic tendencies of the context of the Russian literature development in the 1820-1830 years and we also marked "rish Melodies" influence on the "Irish Theme" appearance in the Russian periodical issues. There were disclosed the reasons of "Eastern Tale" "Lalla Rook" popularity in Russia which coincided with the Russian romantic oriented science popularity and the tendencies of the romantic national originality if taking into account ethnography and folklore. In spite of the fact that the majority of $\mathrm{T}$. Moore's early translations were prosaic and made not from the original texts but with the help of French interpretations of Moore's compositions, his poems became very popular in Russia which was proved by the appearance of traditions, reminiscences from Moore's creative works in the Russian romantic literature and by T. Moore's poetry inclusion into the curriculum of educational establishments.

\section{Acknowledgements}

The research has been carried out within the project 2232 "Interdisciplinary social and humanist research in the context of innovative development and international connections" in the basic part of the state quota of the RF Department of Education and Science.

\section{References}

Girivenko, A.N. (1992). Russian reception of Thomas Moore (Dissertation Abstract). Moscow Pedagogical University by V.I Lenin. Alexeev, M.P. (1982). Russian-English literary interconnections (XVIII century - the first part of the XIX century). Moscow: Nauka. Pletnev, P.A. (1885). Compositions and correspondence (In 3 Vol.). Saint Petersburg: Publishing House by A.F.Panteleev. Vol. 1, p.63. Ivanenko, M. (1830). Character of style and writings of Thomas Moore (Speeches and poems pronounced at special events in the Noble University School). Moscow: Publishing House by Reshetnikov.

Bauzhite, G.A. (1958). "rrish Melodies" of Thomas Moore and national-liberty movement. In Scientific notes of Moscow State University by M.V.Lomonosov. Moscow: Moscow University Publishing House, Iss. 196, 275-301.

Saruhanyn, A.P. (1962). To the question of English-Irish literary connections in XVIII - XIX century. From the history of literary connections in XIX century. Moscow: GIHL.

Ochkin, A.N. (1822). Some facts about Thomas Moore. Blagonamerenny, 28 (19), 45-52.

Krachkovsky, I.Y. (1950). Essays from the history of Russian Arabic science. Moscow-Leningrad: State Publishing House.

Oksman, Y.G. (1922). Struggle with Byron at the Alexander and Nicolas period. Nachala, 2, 241-288.

Moore, T. (1910). The poetical works. London-New York: Press.

Moore, T. (1829). Epicurean. Translated by V.M. Altseva. Russian spectator. 17-20, 105-142.

Moore, T. (1829). Epicurean. Translated by A. Savitsky. St.Petersburg: Publishing House by Semen Selivanovsky.

Maslov, V.I. (1915). The primary Byron's period in Russia. Kiev: The Publishing House by I.M. Rozeta.

Belinsky, V.G. (1955). Complete collection of compositions (In 13 v.). Moscow: GIHL, Vol. VIII. 
